\title{
The Impact OF Operational Quality: A Supply Chain VieW
}

\author{
Vijay R. Kannan \\ Department of Business Administration \\ Utah State University \\ Logan, UT 84322-3510, USA \\ Phone: (435) 797-7212 \\ Fax: (435) 797-2634 \\ Email: v.kannan@usu.edu \\ Keah Choon Tan \\ Department of Management \\ University of Nevada, Las Vegas \\ Las Vegas, NV 89154-6009, USA \\ Tel: (702) 895-3873 \\ Fax: (702) 895-4370 \\ kctan@unlv.nevada.edu
}

September 18, 2004 


\title{
The IMPACT OF Operational Quality: A SuPPly Chain VieW
}

\begin{abstract}
Leveraging supply chains to create value and enhance competitiveness has generated considerable interest in both academic and practitioner communities. One of the key drivers of value creation within the supply chain is quality. Companies can actively influence quality not only through their own design and manufacturing practices, but by involving suppliers and customers in their quality initiatives. This study provides details of a study that examines from a supply chain perspective, the impact of operational quality practices. Specifically it examines how firms can, by leveraging knowledge about customers' expectations, supplier commitment to quality, and their own internal quality practices, impact measures of quality indicative of a firm's success in the market place. Regression models demonstrate that exploiting operational quality practices both internally and externally positively impacts measures of product quality and customer service. More importantly, they suggest that externally focused efforts are not only perceived by firms to be of greater importance, they have as strong an impact on performance as internally focused efforts.
\end{abstract}

Keywords: Quality Management, Supply Chain, Empirical Research, Regression 


\section{Introduction}

The subject of supply chains has generated considerable interest within both the business and academic communities. Firms seeking to improve performance are reexamining not only how they get products into their customers' hands but how they can better respond to customers' needs. This has involved critically reexamining all aspects of their supply chain from how they ascertain what customers want and assessing whether they are responding to this, to how they utilize their own and their suppliers' capabilities to fulfill their obligations to customers. Quality, customer focus, outsourcing, and value added have become synonymous with firms' efforts to respond to increasing competition, and how they are leveraging their supply chains to this end.

Much of the early literature on supply chains focused on issues related to the management of material and information flows. The supply perspective of supply chain management for example (Tan et al., 1998) reflects the rationalizing and streamlining of the supply base, and involving suppliers in key decision making processes such as product development and sourcing (e.g., Krause, 1997, Monczka et al., 1994, Ragatz et al., 1997), while the logistics perspective reflects efforts to replace inventory with information, and streamlining and coordinating transportation and distribution processes (e.g., Davis, 1993, Houlihan, 1987, Scott and Westbrook, 1991). More recent studies have examined the concept of supply chain integration, the coordination of design, production, and distribution activities across the supply chain (e.g., Frohlich and Westbrook, 2001, Lummus et al., 1998, Morash and Clinton 1998).

To date, relatively little attention has been paid to the issue of quality in a supply chain context. While several authors have spoken of the importance of quality across the supply chain (e.g., Coyle et al., 1996, Johnson and Wood, 1996), few have in fact taken a chain wide perspective of quality. In contrast, quality management at the firm level has received 
considerable attention. Several studies have for example identified the core elements of quality management systems (e.g., Ahire et al., 1996, Black and Porter, 1996, Saraph, 1989), while others have examined linkages between these factors and organizational performance (e.g., Anderson et al., 1994, 1995, Dow et al., 1999, Flynn et al., 1995, Samson and Terziovski, 1999). As a result, much is now known about how to develop a quality strategy and how to deploy resources in the context of this strategy. In particular, having a strong customer focus (e.g., Anderson et al., 1994, Ahire et al., 1996, Black and Porter, 1996), and paying careful attention to supplier quality (e.g., Flynn et al., 1995, Ahire et al., 1996) are key elements of any quality management strategy. However, while the literature has identified the importance of customers and suppliers in a firm's quality improvement efforts, it has focused largely on strategic quality management. Little empirical evidence exists of either the impact of operational quality practices or quality practices within the supply chain more broadly. How a firm interacts with its supply chain to understand customers needs, and works to ensure that its suppliers' capabilities can meet these needs, is however of some significance.

\section{Supply Chain Quality}

Several studies in the purchasing/logistics/supply chain management literature have examined the positive impact of quality at various interfaces of the supply chain. The impact of

supplier quality (e.g., Burt et al., 2003, Krause, 1997, Kuei et al., 2001, Tracey and Vonderembse, 2000) and the role of buyer/supplier relationships on quality (e.g., Wong et al., 1999) have for example been extensively documented. Similarly, studies have examined the role of quality in logistics (e.g., Read and Miller, 1991, Millen and Maggard, 1997, Millen et al., 1999). Few studies have however explored beyond the immediate customer or supplier interface to develop a broader understanding of quality practice within the supply chain. 
Forker et al., (1997) investigated the impact of quality management practices throughout supply chains on quality as measured by a common customer. They observed that management of supplier quality throughout the chain was directly related to higher levels of quality conformance, reduced variation in quality performance, and reduced production cost. Salvador et al., (2001) examined how interactions between an organization and its suppliers and customers to achieve high material quality impact time based performance. These interactions were found to provide information that can be used to improve operations control and coordination, thereby positively influencing time based performance. Kanji and Wong (1999) examined the impact of commitment to suppliers and customers on a broad measure of supply chain performance that incorporated both firm performance and measures of customer and supplier satisfaction. They observed not only high levels of commitment to relationship building and continuous improvement, but positive relationships between the two variables. Relationship building and continuous improvement were also shown to positively impact performance. Romano (2002) examined the impact of firm sensitivity to quality certification programs on quality management practices and operational performance. Sensitivity for suppliers was defined as the extent to which a firm used certified suppliers, while for customers it was defined by whether the firm was driven by customer pressure to seek certification. Firms in highly sensitive chains, those in which both customers and suppliers are sensitive to certification, were observed to not only have more advanced quality systems but to more rapidly achieve ISO 9000 certification than others. Firms sensitive on the supplier side also used quality management practices more extensively prior to certification than those that were not. In particular, they had a greater emphasis on the use of in process controls as opposed to inspection based quality management. 
A separate stream of research has examined the relationship between a firm's position within the supply chain and the type and extent of quality management practices it uses. Both Choi and Rungtusanatham (1999) and Rothlein et al., (2002) observed that position within the supply chain has no impact on quality management practice. This is significant in that it has been speculated that in industries such as the automotive industry, quality efforts are driven by assemblers. Assemblers and first tier suppliers would thus be expected to be further along in their quality management initiatives.

\section{Research Questions and Methodology}

As the above discussion suggests, analysis of quality management within the context of a supply chain is still at an early stage. Two weaknesses however are of particular note. First, as is the case with the quality management literature in general, the literature focuses predominantly on strategic quality management. Prior studies in the quality management literature have demonstrated that operational quality practice has a significant impact on organizational performance (Kannan et al., 1999). Romano and Vinelli (2001) also highlighted fundamental differences in operational quality practice between firms that are tightly coordinated with their supply chain partners and those that are not. Beyond this however, there is little evidence of the impact of operational quality practice in the context of a supply chain, and in particular how it affects a firm's performance. This raises the question

Does a positive relationship exist between a firm's internally focused operational quality practices and organizational performance?

Second, prior studies have focused primarily on the producer firm or the supplier interface, with less attention being been paid to the customer interface. More significantly, there has been little attempt to simultaneously assess the impact of internally as well as externally focused 
operational quality management efforts. As the literature suggests however, the success of a firm in leveraging its supply chain depends on its both being able to accurately gauge and respond to customer needs and expectations, and using this to drive its design and production efforts. This raises the questions

Does a positive relationship exist between a firm's externally focused operational quality practices and organizational performance, and

Do a firm's internally and externally focused operational quality practices interact to impact organizational performance.

To obtain data to address these questions, a survey instrument was developed. Survey research is one of the most widely used methods for collecting primary data, particularly when studying unexplored research areas and where meaningful secondary data are not available. Much of the prior research in both quality and supply chain management has been survey based. Surveys not only enable the solicitation of empirical data that reflects contemporary business practice, they enable large samples to be gathered from a diverse population. A review of the literature and discussions with industry professionals was initially used to identify thirty seven indicators of operational quality. Seven of these pertained to customer quality, and fifteen each to supplier quality and internal process quality. Survey questions were developed that sought information on the importance of the indicators as part of a firm's efforts to manage quality within its supply chains. In addition, information was sought on product quality and competitiveness, the two dependent variables of interest. These variables directly reflect the success of efforts to leverage the supply chain to achieve quality. Respondents were asked to assess their firm's performance on these metrics relative to that of their competitors.

The survey instrument was pre-tested by senior purchasing and materials managers and where necessary modified to improve the clarity and validity of questions. Pre-tests were not 
included in subsequent analysis. The revised survey was sent to senior purchasing and materials managers of manufacturing firms in the United States identified from Institute for Supply Management (ISM) and the Educational Society for Resource Management (APICS) membership lists. The two membership lists were combined, and any duplicate names removed. A survey was mailed to each respondent, followed by a reminder postcard two weeks later. A further two weeks later, a duplicate survey was mailed to those yet to respond. Fifteen hundred surveys mailed out yielded two hundred and forty three useable responses. Of these, one hundred and seventy eight came from finished goods manufacturers, the remainder coming from component and raw materials producers. To test for non-response bias, surveys were separated into two groups based on return date, late arriving surveys considered representative of nonrespondents (Armstrong and Overton, 1977, Lambert and Harrington, 1990). t tests of sales, number of employees and several randomly selected questions indicated there were no statistically significant differences in mean responses were observed, indicating the absence of non-response bias. Similar tests comparing responses from the two survey populations (APICS and ISM) also indicated no statistically significant differences, allowing the two samples to be merged.

To verify that survey scales measured the corresponding construct and were reasonably free of measurement error, reliability analysis was carried out using the Cronbach's $\alpha$ measure (Cronbach, 1951). For each scale, the value of alpha returned was in excess of $0.90^{1}$, well in excess of the minimum generally acceptable value of 0.70 (Nunnally, 1988). Factor analysis was used to reduce the Customer Quality, Supplier Quality, and Internal Process Quality scales to their constituent factors. Principal Components Analysis was used to extract factors with eigen

\footnotetext{
${ }^{1}$ The customer quality, supplier quality, and internal process quality scales returned values of $\alpha$ of $0.9004,0.9036$, and 0.9053 respectively.
} 
values greater than 1, and Varimax rotation was used to obtain a more interpretable factor matrix. The Bartlett Test of Sphericity and the Kaiser-Meyer-Olkin measure of sampling adequacy were used to validate the use of factor analysis. Items with factor loadings lower than 0.50 were dropped from subsequent analysis (Nunnally, 1988).

The seven customer quality indicators loaded onto a single factor, to be referred to as customer input (CI, Table 1). Nine of the supplier quality indicators similarly loaded onto a single factor, to be referred to as supplier quality (SQ). Five indicators did not load onto this factor nor did they have acceptable factor loadings on any of the other factors ${ }^{2}$. The fifteen internal process quality indicators formed three distinct factors. Nine loaded onto a factor reflecting quality efforts during product design. This factor is referred to as design quality (DQ). Four indicators combined with the remaining indicator from the supplier quality scale, supplier efforts to promote JIT, to form a factor reflecting efforts to adopt practices associated with JIT systems. This factor is referred to as JIT Quality (JQ). The remaining two indicators formed a factor reflecting efforts to establish and maintain the integrity of production processes. This is referred to as Process Integrity (PI). The five factors accounted for fifty-seven percent of total variance. Tukey multiple comparisons of mean responses indicated that firms consider customer input (mean score $=4.09$ ) and supplier quality (4.12) to be of greatest but equal importance. Similarly, design quality (3.49), JIT quality (3.53) and process integrity (3.55) were considered to be of equal importance. These results suggest that firms are more focused on externally as opposed to internally focused quality practices. Whether this is the result of their being proactive in focusing on the supply chain as a whole or already having high enough levels of internal quality that they are no longer a priority, is however not clear.

2 These reflected the importance of testing capability, commitment to quality, process capability, commitment to continuous improvement, and efforts to eliminate waste when selecting suppliers. 


\begin{tabular}{|c|c|c|}
\hline Factor & Scale Item & $\begin{array}{l}\text { Factor } \\
\text { Loading }\end{array}$ \\
\hline \multirow{7}{*}{$\begin{array}{l}\text { Customer } \\
\text { Input (Cl) }\end{array}$} & 1. Making it easier for customer's to seek assistance & .778 \\
\hline & 2. Successfully resolving customer complaints & .778 \\
\hline & 3. Understanding how customers use your products and services & .764 \\
\hline & 4. Employing routine follow up procedures for customer inquiries or complaints & .728 \\
\hline & 5. Determining key factors for improving customer satisfaction & .679 \\
\hline & 6. Determining future customer expectations & .665 \\
\hline & 7. Employing a customer satisfaction measurement system & .574 \\
\hline \multirow{9}{*}{$\begin{array}{c}\text { Supplier } \\
\text { Quality (SQ) }\end{array}$} & 1. Suppliers establish and document their quality system & .785 \\
\hline & 2. Suppliers ensure that quality policy is understood, implemented, and maintained & .778 \\
\hline & 3. Suppliers verify that quality activities comply with planned quality system & .760 \\
\hline & 4. Suppliers ensure that purchased parts and materials conform to their specifications & .749 \\
\hline & 5. Suppliers have a comprehensive quality audit system in place & .722 \\
\hline & 6. Suppliers ensure that crucial processes are carried out under controlled conditions & .705 \\
\hline & 7. Suppliers maintain procedures to control and verify the design of the product & .664 \\
\hline & 8. Suppliers investigate causes of non conformance and take corrective actions & .643 \\
\hline & 9. Suppliers maintain a facility wide documented preventive maintenance program & .504 \\
\hline \multirow{9}{*}{$\begin{array}{c}\text { Design } \\
\text { Quality (DQ) }\end{array}$} & 1. Modular design of component parts & .752 \\
\hline & 2. Use of concurrent engineering & .693 \\
\hline & 3. Using standard component parts & .658 \\
\hline & 4. Considering manufacturability and assembly during in product design & .650 \\
\hline & 5. Early supplier involvement in product design & .631 \\
\hline & 6. Use of value analysis/engineering & .629 \\
\hline & 7. Simplifying the product & .566 \\
\hline & 8. Use of quality function deployment & .533 \\
\hline & 9. Designing quality into the product & .529 \\
\hline \multirow{5}{*}{$\begin{array}{l}\text { JIT Quality } \\
\text { (JQ) }\end{array}$} & 1. Reducing lot size & .776 \\
\hline & 2. Suppliers efforts in promoting JIT principles & .638 \\
\hline & 3. Reducing inventory to expose manufacturing and scheduling problems & .623 \\
\hline & 4. Reducing setup time & .617 \\
\hline & 5. Reducing the supplier base & .579 \\
\hline \multirow{2}{*}{$\begin{array}{c}\text { Process } \\
\text { Integrity (PI) }\end{array}$} & 1. Use of statistical process control & .707 \\
\hline & 2. Use of preventive maintenance & .502 \\
\hline
\end{tabular}

\section{Table 1: Factor Analysis}

For each performance measure, multiple linear regression analysis was used to test relationships with the five factors derived from the factor analysis. Three interaction terms were also included. An underlying premise of the quality movement is that products should reflect customer needs. Moreover, in the context of a supply chain, firms will be motivated to work closely with customers to ensure not only that customer needs are met, but in a manner that effectively leverages the firm's design capabilities. It thus follows that design processes and 
assessment of and response to customer needs, are related. This suggests an interaction between variables CI and DQ. It is well documented that a firm's ability to reap the benefits of JIT depends not only on the quality of the supply process but also on the integrity of internal processes. Poor quality incoming materials can result in the need to carry additional material inventory, poor finished goods quality, or delayed delivery. Similarly, internal processes that fail to perform at anticipated levels can result in disruptions to internal supply processes. This suggests interactions between variable JQ and variables SQ and PI. The resulting models were thus of the form

Performance $(\mathrm{PQ}, \mathrm{CS})=\alpha+\beta_{1} \mathrm{CI}+\beta_{2} \mathrm{SQ}+\beta_{3} \mathrm{DQ}+\beta_{4} \mathrm{JQ}+\beta_{5} \mathrm{PI}+\beta_{6} \mathrm{CI} \times \mathrm{DQ}+\beta_{7} \mathrm{JQ} \times \mathrm{SQ}+\beta_{8} \mathrm{JQ} \times \mathrm{PI}$

Results indicate that both regression models are significant $(\alpha=0.05$, Table 2$)$. The Durbin-Watson statistic and normal probability plots also indicated that residuals are independent and normally distributed. All significant regression coefficients in both models exhibit the correct sign, suggesting that they are positively related to the performance measures and that the results are consistent with underlying theory.

\begin{tabular}{llc}
\hline \multicolumn{1}{c}{$\begin{array}{c}\text { Performance } \\
\text { Measure }\end{array}$} & \multicolumn{1}{c}{ Model } & $\mathbf{R}^{2}$ \\
\hline Product Quality (PQ) & $\mathrm{PQ}=4.335+0.263 \mathrm{CI}+0.144 \mathrm{SQ}+0.096 \mathrm{DQ}+0.081 \mathrm{PI}^{*}+0.088 \mathrm{CI} \times \mathrm{DQ}^{*}$ & 0.21 \\
Customer Service (CS) & $\mathrm{CS}=4.076+0.327 \mathrm{CI}+0.105 \mathrm{DQ}+0.126 \mathrm{JQ}$ & 0.21 \\
\hline
\end{tabular}

*Significant at $\alpha=0.10$

Table 2: Regression Models

\section{Discussion}

Four of the five factors and the interaction between customer input and design quality significantly impact product quality. As expected, customer input is positively related to product quality, and indeed yielded the highest regression coefficient $(\beta=0.263)$. This is consistent with findings from the quality literature (e.g., Ahire et al., 1996, Anderson et al., 1994, Black and 
Porter, 1996) that address the need for quality management strategy to be driven by a strong customer focus. However, the results here illustrate the importance of the information gathering and feedback process with regard to customers. Not only is it necessary to have a quality management strategy that is responsive to the needs of the marketplace, specific mechanisms need to be in place to elicit information about current customer needs, whether these are being met or not, and how to respond as these needs change. This reflects a key premise of supply chain management that information flow is a key tool in linking members of the chain. Supplier quality is also positively related to product quality. Poor quality inputs compromise overall product quality. Firms that themselves are committed to achieving high levels of product quality will have their efforts undermined if their suppliers do not themselves have established quality systems in place and cannot verify the quality of their products. This is consistent with prior findings in the supply chain management regarding the role of suppliers in achieving quality (e.g., Kanji and Wong, 1999). The result is also consistent with those in the quality management literature regarding supplier relations, and those in the purchasing literature regarding the importance of certifying key suppliers' products and processes. However, the result here stresses the impact of specific actions aimed at ensuring quality in the supply process in addition to the need to build closer relationships with suppliers.

Design quality, and more importantly its interaction with customer input, is positively related to product quality. This reiterates the fact that it is important not only to have effective design processes, as suggested in the quality management literature, but that they adequately reflect customer input. It also highlights the need for mechanisms that allow for effective dissemination of information between customers and product developers. The lack of mechanisms for communicating product design features within and across organizational 
boundaries has in the past hindered efforts to involve customers in design processes (Govers, 2001, Martins and Aspinwall, 2001). The results here however demonstrate that the interaction between customer input and design process is a key determinant of product quality. The positive coefficient of the interaction term also suggests that customer input and design quality should be implemented simultaneously so that their combined effect can be exploited. While the relationship between process integrity and product quality is significant, it is not as strong as relationships between other independent variables and product quality. The emphasis in product quality is clearly on meeting customer needs, but the implication is that designs that accomplish this can be compromised if quality is not supported during the production process. Somewhat surprisingly, neither JIT quality nor its interactions with supplier quality and process integrity have a significant impact on product quality. This may be a reflection of the fact that the adoption of JIT is just one way to achieve high levels of quality. Moreover, coupled with the relatively low coefficient for the process integrity factor, it may indicate that ultimately it is the ability of the product design to meet expectations that is crucial in evaluations of product quality rather than how the product was produced.

Three factors positively impact customer service. Similar to the product quality model, customer input has the highest regression coefficient $(\beta=0.327)$. It is to be expected that a commitment to identifying and more importantly responding to customer needs, will be viewed favorably by customers. This will in turn be reflected in internal measures of customer service, for example measures of customer satisfaction. Somewhat surprisingly given its insignificant relationship with product quality, just in time quality is also positively related to customer service. This suggests that a firm's ability to respond rapidly to customer needs is a key driver of customer satisfaction. It may also be a reflection of satisfaction with the manufactured quality of 
products. Design quality also positively impacts customer service. As suggested above, this may be a reflection of customers' favorable perceptions towards a firm's ability to respond accurately to feedback regarding their needs and expectations. Neither supplier quality nor process integrity have a significant impact on customer service, nor do any of the three interaction terms. This is consistent with the fact that customers are concerned with whether products meet their needs in a timely manner, and not with the details of how this is accomplished.

\section{Conclusions}

This study sought to examine how by considering operational quality both internally and externally across the supply chain, firms can positively impact measures of quality typically considered important to customers. The results demonstrate the importance of not only having a strong internally focused quality effort, but that externally focused efforts involving customers and suppliers have a considerable impact on product and customer service quality. In particular, major findings are that customer input has a significant impact on both product quality and customer service, and that firms need to carefully assess customer expectations and use what is learned to drive product design activities. While these results have been alluded to in the quality management literature, they are distinct in that they are based on specific operational tactics firms can adopt to involve customers and suppliers in their own quality management efforts. Moreover, they are based on a firm's interactions with its supply chain partners rather than the firm acting in isolation. The results are also consistent with prior findings from the supply chain management literature that, from the standpoint of strategic quality management, address the importance of managing relationships within the supply chain.

The results presented here represent an initial effort to understand how quality can be improved by leveraging the day to day operational tactics of a broad set of participants within the 
supply chain as opposed to those of a firm and its immediate upstream or downstream partners. Additional work is needed to examine the specific mechanisms by which interactions between supply chain participants contribute to quality improvements and how these can be successfully implemented. Work is also needed to better understand the relative impact of specific practices at different points in the supply chain. Another key unresolved issue is how to assess the relative contribution to quality improvements of various participants in the supply chain, and how improvement efforts and rewards should be shared so as to best serve the supply chain as a whole. Greater understanding of these issues will enable firms to more effectively leverage their supply chains thereby increasing the value that they create.

\section{References}

Ahire, S.L., Golhar, D.Y., and Waller M.A., (1996) "Development and Validation of TQM Implementation Constructs", Decision Sciences, Vol. 27, No. 5, pp. 23-56.

Anderson, J.C., Rungtusanatham, M., and Schroeder, R.G., (1994) “A Theory of Quality Management Underlying the Deming Management Method", Academy of Management Review, Vol. 19, No. 3, pp. 472-509.

Anderson, J.C., Rungtusanatham, M., Schroeder, R.G., and Devaraj, S., (1995) “A Path Analytic Model of a Theory of Quality Management Underlying the Deming Management Method: Preliminary Empirical Findings", Decision Sciences, Vol. 26, No. 5, pp. 637-658.

Armstrong, J. S., and Overton, T.S., (1977) "Estimating Non-Response Bias in Mail Surveys", Journal of Marketing Research, Vol. 14, pp. 396-402.

Black, S.A., and Porter, L.J., (1996), "Identification of the Critical Factors of TQM", Decision Sciences, Vol. 27, No. 1, pp. 1-22.

Burt, D.N., Dobler, D.W., and Starling, S.L., (2003) World Class Supply Management, Irwin McGraw Hill, Boston.

Choi, T.Y., and Rungtusanatham, M., (1999) "Comparison of Quality Management Practices: Across the Supply Chain and Industries", Journal of Supply Chain Management, Vol. 35, No. 1, pp. 20-27.

Coyle, J.J., Bardi, C.J., and Langley, C.J., (1996), The Management of Business Logistics, West Publishing Company, St Paul.

Cronbach, L.J., (1951), "Coefficient Alpha and the Internal Structure of Tests", Psychometrika, Vol. 16, pp. 297-334. 
Davis, T., (1993) “Effective Supply Chain Management”, Sloan Management Review, Vol. 12, pp. 35-46.

Dow, D., Samson, D., and Ford, S., (1999), "Exploding the Myth: Do All Quality Management Practices Contribute to Superior Quality Performance?" Production and Operations Management, Vol. 8, No. 1, pp. 1-27.

Flynn, B.B., Schroeder, R.G., and Sakakibara, S., (1995), "The Impact of Quality Management Practices on Performance and Competitive Advantage", Decision Sciences, Vol. 26, No. 5, pp. 659-692.

Forker, L.B., Mendez, D., and Hershauer, J.C., (1997) "Total Quality Management in the Supply Chain: What is its Impact on Performance", International Journal of Production Research, Vol. 35, No. 6, pp. 1681-1701.

Frohlich, M. T., and Westbrook, T., (2001) "Arcs of Integration: An International Study of Supply Chain Strategies", Journal of Operations Management, Vol. 19, No. 2, pp. 185-200.

Govers, C.P.M., (2001) “QFD Not Just a Tool But a Way of Quality Management”, International Journal of Production Economics, Vol. 69, No. 22, pp. 151-159.

Houlihan, J.B., (1987) "International Supply Chain Management", International Journal of Physical Distribution and Materials Management, Vol. 17, No. 2, pp. 51-66.

Johnson, J.C., and Wood, D.F., (1996) Contemporary Logistics, Prentice Hall, Upper Saddle Creek.

Kanji, G.K., and Wong, A., (1999) "Business Excellence Model for Supply Chain Management", Total Quality Management, Vol. 10, No. 8, pp. 1147-1168.

Kannan, V.R., Tan, K.C., Handfield, R.B., and Ghosh, S., (1999), "Tools and Techniques of Quality Management: An Empirical Investigation of Their Impact on Performance", Quality Management Journal, Vol. 6, No. 3, pp. 34-49.

Krause, D.R., (1997) "Supplier Development: Current Practices and Outcomes", International Journal of Purchasing and Materials Management, Vol. 33, No. 2, pp. 12-19.

Kuei, C., Madu, C.N., and Lin, C., (2001) "The Relationship between Supply Chain Quality Management Practices and Organizational Performance", International Journal of Quality and Reliability Management, Vol. 18, No. 8, pp. 864-872.

Lambert, D.M., and Harrington, T.C., (1990), “Measuring Non-Response Bias In Mail Surveys", Journal Of Business Logistics, Vol. 11, No. 2, pp. 5-25.

Lummus, R.R., Vokurka, R.J., and Alber, K.L., (1998) "Strategic Supply Chain Planning" Production and Inventory Management Journal, Vol. 39, No. 3, pp. 49-58.

Martins, A., and Aspinwall, E.M., (2001) "Quality function deployment: An empirical study in the UK", Total Quality Management, Vol. 12, No. 5, pp. 575-588.

Millen, R.A., and Maggard, M., (1991) "The Change in Quality Management Practices: 1995 Versus 1991”, Total Quality Management, Vol. 8, No. 4, pp. 173-179.

Millen, R., Sohal, A., and Moss, S., (1999) "Quality Management in the Logistics Function: An Empirical Study", International Journal of Quality and Reliability Management, Vol. 16, No. 2, pp. 166-180. 
Monczka, R.M., Trent, R.J., and Callahan, T.J., (1994) "Supply Base Strategies to Maximize Supplier Performance", International Journal of Physical Distribution and Logistics, Vol. 24, No. 1, pp. $42-54$.

Morash, E. A., and Clinton, S. R., (1998) "Supply Chain Integration: Customer Value Through Collaborative Closeness Versus Operational Excellence", Journal of Marketing Theory and Practice, Vol. 6, No. 4, pp. 104-120.

Nunnally, J., (1988), Psychometric Theory, McGraw-Hill, New York.

Ragatz, G.L., Handfield, R.B., and Scannell, T.V., (1997) "Success Factors for Integrating Suppliers into New Product Development", Journal of Production Innovation Management, Vol. 14, pp. 190-202.

Read, W.F., and Miller, M.S., (1991) “The State of Quality in Logistics”, International Journal of Physical Distribution and Logistics Management, Vol. 21, No. 6, pp. 32-47.

Romano, P., (2002) "Impact of Supply Chain Sensitivity to Quality Certification on Quality Management Practices and Performances", Total Quality Management, Vol. 13, No. 7, pp. 981 1000 .

Romano, P., and Vinelli, A., (2001) "Quality Management in the Supply Chain Perspective", International Journal of Operations and Production Management, Vol. 21, No. 4, pp. 446-460.

Rothlein, C., Mangiameli, P., and Ebrahimpour, M., (2002) "Quality in U.S. Manufacturing Industries: An Empirical Study”, Quality Management Journal, Vol. 9, No. 3, pp. 48-66.

Salvador, F., Forza, C., Rungtusanatham, M., and Choi, T.Y., (2001) "Supply Chain Interactions and Time Related Performance: An Operations Management Perspective", International Journal of Operations ad Production Management, Vol. 21, No. 4, pp. 461-475.

Samson, D., and Terziovski, M., (1999), "The Relationship between Total Quality Management Practices and Operational Performance”, Journal of Operations Management, Vol. 17, pp. 393409.

Saraph, J.V., Benson, P.G., and Schroeder, R.G., (1989), “An Instrument For Measuring The Critical Factors Of Quality Management”, Decision Sciences, Vol. 20, No. 4, pp. 810-829.

Scott, C., and Westbrook, R., (1991) "New Strategic Tools for Supply Chain Management", International Journal of Physical Distribution and Logistics, Vol. 21, No. 1, pp. 23-33.

Tan, K.C., Kannan, V.R., and Handfield, R.B., (1998) "Supply Chain Management: Supplier Performance and Firm Performance", International Journal of Purchasing and Materials Management, Vol. 34, No. 3, pp. 2-9.

Tracey, M., and Vonderembse, M.A., (2000) "Building Supply Chains: A Key to Enhancing Manufacturing Performance”, Mid American Journal of Business, Vol. 15, No. 2, pp. 11-20.

Wong, A., Tjosvold, D., Wong, W.Y.L, and Liu, C.K., (1999) "Relationships for Quality Improvement in the Hong Kong - China Supply Chain, International Journal of Quality and Reliability Management, Vol. 16, No. 1, pp. 24-41. 